\title{
KOLABORASI TEKNIK OPTIMASI WEB UNTUK MENDAPATKAN POPULARITAS TERBAIK DI MESIN PENCARI, AKSES YANG CEPAT, KEMUDAHAN AKSES, DAN KEAMANAN
}

\author{
Rosida, Patah Herwanto \\ Program Studi Teknik Informatika \\ STMIK Indonesia Mandiri, Jl.Jakarta No.79 Bandung \\ Email : rosida21@yahoo.com, pherwanto@stmik-im.ac.id
}

\begin{abstract}
ABSTRAK
Optimasi web merupakan sesuatu yang harus dilakukan jika menginginkan web yang dibangun mendapatkan popularitas terbaik di suatu mesin pencari, dengan begitu maka bisa dipastikan situs web tersebut akan mendapatkan banyak pengunjung karena sebagian pencari informasi melakukan pencarian melalui mesin pencari. Teknik yang dapat dilakukan untuk optimasi web sepertinya tidak cukup hanya Search Engine Optimization (SEO) saja, melainkan perlu optimasi pada sisi yang lain seperti pada sisi konten, desain, performa, dan aksesibilitas. Dengan begitu maka diharapkan situs web bukan hanya memiliki rangking terbaik di mesin pencari saja tetapi juga memiliki konten yang rapi, performa yang baik, serta kemudahan akses bagi para pengunjungnya.
\end{abstract}

Kata kunci : optimasi web, search engine optimization, performa web.

\section{PENDAHULUAN}

Dewasa ini hampir semua perusahaan ataupun instansi pemerintah atau swasta hampir dipastikan mempunyai situs web yang digunakan sebagai media promosi atau publikasi seperti produk, kebijakan, hasil penelitian, dan lain lain. Tetapi terkadang situs web yang dibuat hanya mementingkan pada sisi antarmuka yang indah pada sisi estetika saja terkadang mereka lupa hal-hal yang perlu diperhatikan dalam mempromosikan situs web mereka sehingga tujuan awal dari pembuatan situs web tersebut tercapai dengan baik.

Untuk membuat suatu situs web menjadi lebih baik dari sisi popularitas di mesin pencari, pengaksesan yang cepat, kemudahan akses dan keamanan, maka diperlukan perhatian khusus dalam pembuatan situs web tersebut, banyak kakas yang bisa digunakan untuk mencapai hal tersebut seperti web analitic dari google, audit seo dari alexa, dan masih banyak lagi. Dari banyak kakas yang tersedia tersbut seakan tidak berarti seandaikan perancang atau pembuat situs web tersebut tidak paham tahapan tahapan yang harus dilalui dalam pembuatan situs web sehingga menghasilkan situs web yang sesuai dengan harapan. Dalam kajian ini diuaraikan beberapa tahapan dalam mengoptimalkan situs web yang dapat mempermudah kita melakukan tersebut. 


\section{PEMBAHASAN}

Hampir seluruh pengguna internet dipastikan akan selalu mencari infromasi yang diinginkan melalui mesin pencari dan tidak jarang dari mereka hanya membuka hasil pencarian dari mesin pencari tersebut hanya sampai pada halaman satu saja dengan begitu hasil pencarian yang terdapat pada halaman dua dan seterusnya kemungkinan besar tidak akan dilirik oleh pencari informasi tersebut.

Untuk membuat halaman web supaya berada pada halaman satu di mesin pencari, memang dibutuhkan suatu teknik khusus yang biasa disebut Search engine Optimization (SEO), dan membutuhkan waktu yang relative lama untuk mencapai keberhasilan tersebut. dan kita masih membutuhkan beberapa optimasi tambahan pada halaman situs web sehingga mempunyai unjuk kerja yang lebih baik seperti optimasi pada content, desain, performance, dan accessibility.

Untuk mengimplementasikan kolaborasi teknik optimasi situs web secara optimal ada beberapa tahapan yang harus dilakukan secara berurutan yaitu dimulai dari optimasi desain, optimasi halaman situs, optimasi unjuk kerja, optimasi kemudahan akses dan optimasi SEO.

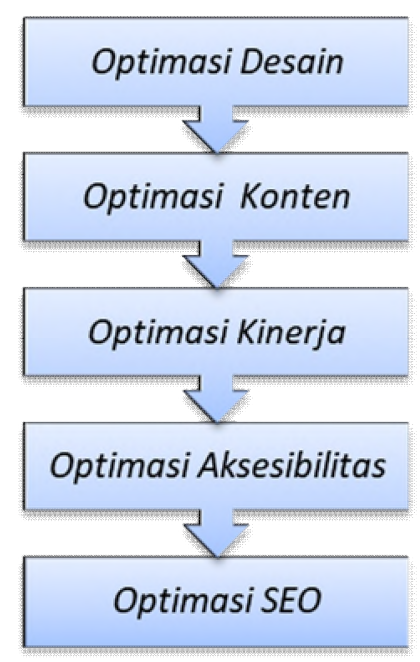

Gambar 1. Model Optimasi web terintegrasi

\subsection{Optimasi Desain}

Desain merupakan satu hal yang sangat penting dalam membuat situs web karena desain menentukan tingkatan kualitas dari suatu situs web. Ada beberapa hal yang di optimasi pada desain ini diantaranya adalah : 


\section{Standarisasi}

Ada beberapa standarisasi pada pada dokumen seperti DOCTYPE (Document Type Declaration), Charset dan W3S. DOCTYPE merupakan deklerasi yang biasanya disimpan di awal halaman HTML yang berfungsi untuk mengidentifikasi jenis dokumen HTML sehingga browser dapat menentukan bagaimana memperlakukan kode pada halaman HTML tersebut. Sedangkan Charset digunakan untuk menerjemahkan bit-bit di dalam halaman HTML menjadi karakter yang ditetapkan pada tag charset tersebut. W3C adalah standarisasi yang dikeluarkan oleh World Wide Web Consortium mengenai struktur penulisan dokumen HTML.

\section{Kualitas tataletak}

Beberapa hal yang harus di perhatikan dalam mengukur kualitas tataletak seperti desain table, penggunaan frame atau Iframe, dan penngunaan flash.

\section{Keamanan}

Konfigurasi server merupakan suatu hal yang penting dalam menjaga keamanan suatu situs web, maka dari itu server harus dipersiapkan dengan baik ada beberapa yang biasa menjadi perhatian dalam configurasi server ini diantaranya adalah menyembunyikan informasi tentang sistem operasi, teknologi server yang digunakan serta Bahasa pemograman yang dipakai dalam membangun situs web tersebut. Selain itu ip6 compability harus menjadi perhatian yang serius sebab pada akhirnya ip4 akan habis juga dan akan digantikan oleh ip6 dan diluar sana sudah banyak yang menngunakan ip6. Jadi alangkah lebihbaik jika server tempat kita menyimpan dokumen situs web benar benar sudah mengimplementasikan ip6 tersebut. keamanan dari dns juga harus diperhatikan salah satu implementasi keamanan dns bisa menggunakan DNSSEC.

Melindungi alamat email yang terdapat di halaman situs web perlu dilakukan sehingga alamat email tersebut tidak bisa di baca dan di parsing oleh perangkat lunak pembaca alamat email, dalam hal ini perlindungan email bisa dilakukan dengan cara mengganti alamat email dalam bentuk text menjadi gambar.

Beberapa browser mempunyai kemamnpuan untuk filter data yang kemungkinan berpotensi merupakan serangan, tetapi kemampuan browser ini kadangkala bisa di disable, maka dari itu kita perlu mengatur header $X$-Xss-Protection menjadi aktif atau 
mode di set menjadi block yang menandakan jika terjadi serangan maka seluruh halaman web yang aktif akan di block.

Mengatur dan menerapkan Content-Security-Policy sehingga memungkinkan server hanya akan mengirimkan data kepada server berdasarkan pada permintaan yang syah jika permintaan dinyatakan tidak syah maka akan membuat noyifikasi kepada pengguna.

Pengamanan yang paling baik adalah pengamanan komunikasi data dengan menggunakan protocol HTTPS, dengan protocol https ini maka lalulintas data antara server dan client dalam hal ini browser sudah dalam keadaan terenkripsi.

\subsection{Optimasi Konten}

Ada beberapa hal yang menjadi perhatian pada optimasi kontent ini diantaranya yaitu :

\section{Kinerja halaman web}

Kinerja halaman web ini harus sangat diperhatikan karena semakin baik kinerja halaman web ini, itu menandakan bahawa isi dari halaman web ini mempunyai tingkat kualitas yang informasi yang baik, untuk mengukur kinerja halaman web ini biasanya dilakukan perbaindingan antara (text informasi)/(kode program) jika rasionya tinggi maka bisa diasumsikan bahwa halaman web tersebut memiliki informasi yang baik.

\section{Semantic}

Pada suatu halaman web ada beberpa pengaturan yang harus sesuai dengan tingkatannya salah satu diantaranya adalah penggunaan tag $\mathrm{H}$ (Header), penggunaan tag header dengan benar makan akan memudahkan mesin pencari untuk menentukan prioritas tingkat kepentingan suatu informasi tersebut. berikutnya adalah penggunaan microdata pada informasi suatu halaman web dengan micro data ini maka akan memudahkan mesin pencari dalam mengelompokan suatu informasi dalam kelompok kelompok tertentu. Sehingga arti dan makna dari informasi tersebut bisa dengan gampang di definisikan.

\section{Kata Kunci}

Kata kunci merupakan satu kata yang memilki keistimewaan tertentu, karena dengan kata kunci ini mengandung informasi yang terkandung dalam informasi yang 
ada dalam halaman web tersebut. ada dua hal yang harus diperhatikan dalam pembentukan kata kunci ini yaitu yang pertama adalah keterkaitan antara katakunci yang berada di tag title dengan kata kunci yang ada di isi informasi pada halaman web, dengan kata lain maka jangan pernah memberikan judul halaman yang berlainan dengan isi informasi halaman tersebut. Yang kedua adalah kepadatan kata kunci, semakin banyak jumlah keyword di isi dari informasi halaman web tersebut makan katakunci tersebut semakin baik untuk ditampilkan pada judul halaman situs web tersebut.

\begin{tabular}{|c|c|c|c|c|}
\hline $\mathrm{N}$ & Keymord & Courrences & Denity & Density wetetted \\
\hline 1 & 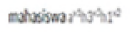 & 14 & $583 \%$ & $514 \%$ \\
\hline 2 & $\tan x^{2}$ & 11 & $458 \%$ & $122 \%$ \\
\hline 3 & $\operatorname{desen} y^{\prime} / z^{2}$ & 10 & $4.17 \%$ & $244 \%$ \\
\hline 4 & illorassi & 8 & 3.335 & $117 \%$ \\
\hline 5 & progrm $a^{6} y^{4}$ & 7 & $2925 \%$ & $188 \%$ \\
\hline 6 & $a b d e m i z^{4}$ & 7 & $292 \%$ & $0.97 \%$ \\
\hline 7 & 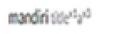 & 6 & $25 \%$ & $27 \%$ \\
\hline 8 & 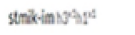 & 6 & $25 \%$ & 2145 \\
\hline 9 & $m$ & 6 & 258 & $0.61 \%$ \\
\hline 10 & inlormethasesetst & 5 & $200 \%$ & $265 \%$ \\
\hline 11 & Wis & 5 & $206 \%$ & $051 \%$ \\
\hline 12 & brupatasta & 5 & $200 \%$ & $361 \%$ \\
\hline
\end{tabular}

Gambar 2. Expression of 1 keyword

(stmik-im.ac.id)

\subsection{Optimasi Kinerja}

Optimasi pada unjuk kerja suatu situs web dimaksudkan supaya halaman situs web tersebut apabila dipanggil melalui suatu browser akan terasa cepat sehingga membuat nyaman dan betah para pengunjung. Ada beberapa hal yang perlu di optimasi untuk mencapai performance dari suatu situs web diantaranya :

\section{Optimasi Download}

Dalam suatu situs web terkadang kita memerlukan berbagi file yang dapat didownload baik melalui web atau melalui ftp, ada beberapa yang perlu di perhatikan suapaya proses download tersebut menjadi lebih cepat yaitu : file yang hendak disediakan untuk didownload sebaiknya di di kompres terlebih dahulu sehingga ukuran file menjadi lebih kecil, file yang telah di konpres biasanya mempunyai file extention . tar.gz, .zip, tar atau $.7 z$ 


\section{Optimasi Pemuatan halaman web}

Waktu pemuatan halaman web yang lama akan membuat pengunjung bosan untuk menunggu dan sebaliknya apabila proses pemuatan lebih cepat mungkin akan membuat betah para pengunjung dan ini akan mendatangkan keuantungan yang lebiih bagi pemilik situs web. Ada beberpa yang dapat dilakukan untuk optimasi pemuatan halaman web ini, diantaranya :

1) Minimalkan permintaan HTTP. Dalam satu halaman web terkadang dibagi menjadi beberapa document yang terpisal missalkan file css yang terbagi menjadi beberapa file, include file yang terkadang fungsi atau procedure yang tidak terpakai ikut disertakan juga, dan lain lain. Untuk meminimalkan permintaan HTTP usahakan gunakan css bukan gambar jika memungkinkan dan jangan terlalu banyak scipt yang dimuat dan jika ada usahakan simpan dibawah halaman.

2) Kurangi waktu respon server. Usahakan waktu repon server 200ms (milidetik) untuk mencapai hal ini gunakan kakas PageSpeed Tools dari google atau Yslow untuk mengevaluasi kecepatan situs dan mendapatkan tip tentang cara meningkatkan kinerja.

3) Aktifkan Kompresi.

4) Aktifkan caching browser.

5) Optimalkan Gambar.

6) Kurangi jumlah plugin yang digunakan di situs.

7) Optimalkan penggunaan $c s s$

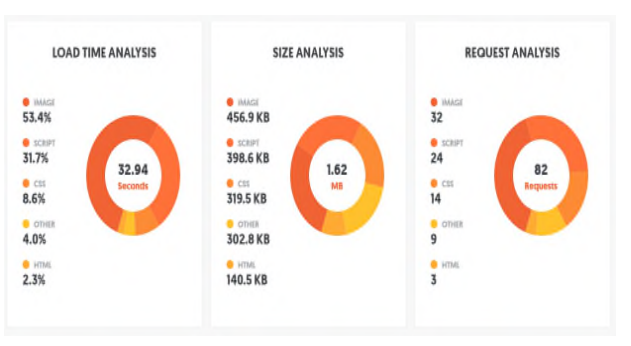

Gambar 3. Analisis halaman situs

(stmik-im.ac.id)

\subsection{Optimasi Aksesibilitas}

Optimasi pada kemudahan akses ini lebih mementingkan pada bagaimana situs web dapat ditampilkan dengan baik di berbagai device yang berbeda seperti pada layar 
monitor komputer, layar smart phone atau pada layar tablet, selain itu ada beberapa hal yang perlu di optimasi untuk mencapai Accessibility dengan maksimal diantaranya adalah :

1. Usability, adalah kemudahan penggunaan situs web yang memiliki tujuan presentasi informasi yang jelas dan ringkas, kurangnya ambiguitas dan penempatan item penting di area yang sesuai. Unsur penting lain dari Usability web adalah memastikan konten bekerja pada berbagai perangkat dan browser.

2. Sharing, memudahkan berbagi halaman web bagi pengunjung, sehingga pengunjung dapat dengan mudah membagikan tautan halaman situs web melalui berbagai media social.

3. Mobile compatibility, memudahkan semua halaman situs web untuk dibuka di perangkat mobile seperti smartphone dan tablet. Dan sudah banyak teknologi yang memudahkan hal ini salah stunya adalah dengan menggunakan berbagai framework responsive untuk mendesain halaman situs web.

\subsection{Optimasi Mesin Pencari (SEO)}

SEO adalah serangkaian proses yang dilakukan secara sistematis untuk mendapatkan jumlah pengunjung yang optimal melalui mekanisme optimasi mesin pencari yang sesuai algoritmanya. Dalam penggunaannya SEO memiliki dua metode yaitu On Page SEO, Off Page SEO.

On Page SEO merupakan cara optimasi halaman web yang di terapkan dibeberapa bagian yaitu :

1. Informasi header seperti page title, meta description, dan meta atribut.

2. Indexsasi seperti meta robot, robot.txt, dan sitemap.

3. Kontent duplikat seperti www riderection, dan link canonical.

4. Multimedia seperti alternative text.

5. Link seperti jumlah link, link juice, single links, follow link dan reliable links.

Sedangkan Off Page SEO adalah optimasi dengan memanfaatkan Link dari halaman situs kita yang berada pada halaman situs orang lain yang mempunyai Page Rank yang tinggi atau disebut juga dengan backlink 


\section{KESIMPULAN}

Faktor lain yang tidak kalah penting dalam membangun situs web selain dari sisi tampilan yang menarik adalah faktor desain, content, Acessibility, dan keamanan, serta bagaimana membuat webite tersebut popular di mesin pencari yang dampak baiknya akan meningkatkan jumlah pengunjung ke situs web tersebut.

Metode Kolaborasi optimasi dalam membuat suatu situs web dapat memberikan acuan dalam melakukan optimasi terhadap situs web yang diinginkan.

Implementasi lebih lanjut dari situs web agar lebih optimal adalah membuat kakas untuk pengecekan apakah optimasi web yang telah dilakukan berhasil atau tidak dengan menampilkan poin poin optimasi yang masih kurang baik, sehingga dapat menjadi acuan dalam mempernbaiki dan mengoptimalkan kembali dengan mudah.

\section{DAFTAR PUSTAKA}

M. Cui and S. Hu, "Search Engine Optimization Research for Situs web promotion", ICM Transp. Manage., China, vol. 4, (2011), pp. 100-103.

Khalil ur Rehman and Muhammad Naeem Ahmed Khan, "The Foremost Guidelines for Achieving Higher Ranking in Search Results through Search Engine Optimization”, International Journal of Advanced Science and Technology, Vol. 52, March, 2013, pp. 101-109.

Melissa Gasparotto, "Search Engine Optimization for the Research Librarian: A Case Study Using the Bibliography of U.S. Latina Lesbian History and Culture", Practical Academic Librarianship: The International Journal of the SLA Academic Division, 2014, pp. 15-34.

H. L. Hsing, H. J. Chen, L. Me. Huang and H. H. Yi, “The application of search engine optimization for internet marketing: An example of the motel web sites", ICCAE Chung Hua University Taiwan, vol. 1, (2010), pp. 380-383. 